\title{
ROLA STANDARDÓW O CHARAKTERZE SOFT LAW W ZAKRESIE KREOWANIA ZOBOWIĄZAŃ W PAŃSTWACH CZŁONKOWSKICH ORGANIZACJI MIĘDZYNARODOWYCH
}

\begin{abstract}
Autor pokazuje, że podstawowe cechy prawa miękkiego mają niewiążący i niesankcjonowany charakter. Pojęcie to wywodzi się z międzynarodowego prawa publicznego, dość specyficznej dyscypliny, opartej całkowicie na faktycznym wpływie podmiotów, a nie na sformalizowanych sankcjach. Jest także źródłem typowych instytucji prawa miękkiego: rezolucji międzynarodowych, międzynarodowych deklaracji, podpisanych, ale nieratyfikowanych umów międzynarodowych itp.

Prawo miękkie jest rodzajem normy społecznej, a nie prawnej. Chociaż nie ma akceptowanej definicji ,miękkiego prawa", zwykle odnosi się ona do każdego pisemnego instrumentu międzynarodowego, innego niż traktat, zawierającego zasady, normy, standardy lub inne deklaracje oczekiwanego zachowania. Miękkie prawo wyraża preferencję, a nie zobowiązanie, które państwo powinno wdrażać lub powinno powstrzymać się od działania w określony sposób. Ta wyrażona preferencja dla pewnych zachowań ma na celu osiągnięcie funkcjonalnej współpracy między państwami w celu osiagnięcia międzynarodowych celów.

Niektórzy uczeni alternatywnie używają terminu „miękkie prawo”, aby odnieść się do słabych lub nieokreślonych postanowień w wiążącym traktacie. Praktyka państw wskazuje, że użycie terminu „miękkie prawo", odnoszącego się do promocyjnego języka niektórych postanowień traktatowych, jest bardziej odpowiednie. Traktaty są wiążące i zawierają zobowiązania prawne, nawet konkretne zobowiązania są sformułowane ogólnie. Mało prawdopodobne jest odwoływanie się do niewiążących instrumentów jako do ,prawa”, miękkich lub twardych, chociaż wielu uczonych zwykle to robi, a dla wygody i prostoty termin ten jest tu używany jako synonim normatywnych stwierdzeń zawartych w instrumentach, które nie są prawnie wiążące.
\end{abstract}

Słowa kluczowe: miękkie prawo, międzynarodowe prawo publiczne.

Pośród problemów wywołujących zainteresowanie nauki prawa znalazło się zagadnienie rozróżnienia „twardego prawa” (prawnie wiążącego, opartego na umowach międzynarodowych) od „miękkiego prawa” (zwanego uchwałodawczym, tworzonego przez organizacje międzynarodowe i niemającego charakteru prawnie wiążącego, choć pomimo tego niosącego pewnego rodzaju zobowiązania ${ }^{2}$ O roli „miękkiego prawa” (soft law) można

${ }^{1}$ Kamil Spryszak, dr nauk prawnych, adiunkt w Zakładzie Prawa Konstytucyjnego, Europejskiego i Międzynarodowego Publicznego na Wydziale Prawa, Administracji i Zarządzania Uniwersytetu Jana Kochanowskiego w Kielcach.

2 Zob. K. Abbott, D. Sindal, Hard and Soft Law in International Governance [w:] International Law: Classic and Contemporary Readings, red. C. KU, P.F. Dietl, Boulder 2009, s. 18. 
mówić zarówno w krajowych systemach prawnych ${ }^{3}$, jak również w prawie międzynarodowym $^{4}$. Sygnalizuje się, że „miękkie prawo” jest wyzwaniem dla prawa międzynarodowego $^{5}$, a zarazem może być skutecznym instrumentem w przeciwdziałaniu negatywnym sutkom nakładających się jurysdykcji trybunałów międzynarodowych ${ }^{6}$. Wskazuje się również, iż „miękkie prawo” wywodzi się z prawa międzynarodowego publicznego, specyficznej gałęzi prawa, opartej w dużej mierze na normowaniu stosunków faktycznego wpływu podmiotów na siebie, a nie typowo rozumianych sankcji?

Jednym z powodów podjętej analizy jest to, iż na podstawie wybranych przykładów, obserwuje się znaczącą rolę soft law w kreowaniu zobowiązań. Podkreślenia wymaga też użyteczność tak rozumianego prawa dla regulacji wielu stosunków opartych na zasadzie kompromisu i współpracy bardziej niż hierarchicznego podporządkowania, które w dzisiejszym świecie stają się coraz bardziej rozpowszechniane. Bowiem specyfika tego prawa polega na tym, że wywodzi swój byt nie tyle ze sformalizowanych, władczych procedur legislacyjnych i obecności zinstytucjonalizowanego przymusu w razie jego nieprzestrzegania, ale ze swoistego kompromisu zgody podmiotów, z którymi wiąże się chęć związania jego postanowieniami ${ }^{8}$.

Zobowiązania stanowią swego rodzaju obietnice podjęcia określonych działań, zazwyczaj składane są przez państwa ubiegające się o członkostwo, które mają na celu dostosowanie własnego porządku wewnętrznego do standardów danej organizacji (Rady Europy, Unii Europejskiej, OBWE). Wartość zobowiązań polega na tym, iż dzięki nim państwa funkcjonujące uprzednio w oparciu o polityczny reżim autorytarny, o ile nie totalitarny, nie mogą w ciągu jednego dnia przekształcić się całkowicie dojrzałe demokracje. Dlatego też, koncepcja swego rodzaju „,szkoły demokracji”, która została generalnie zaakceptowana przez Radę Europy w połowie lat 90. przyznawała powstającym demokracjom pewien określony czas na dostosowanie własnego wewnętrznego porządku politycznego, społecznego i prawnego do standardów Rady Europy. Wobec tego Zgromadzenie Parlamentarne, zwracało się do państw kandydujących $\mathrm{z}$ prośbą o podjęcie wprowadzenia reform $\mathrm{w}$ ramach określonego czasu9 9 .

Zobowiązania odnotowywane są w mniej lub bardziej dokładnej formie. W przypadku Rady Europy znajdują one odzwierciedlenie w opiniach Zgromadzenia Parlamentarnego przekazywanych Komitetowi Ministrów. Czasem przyjmowane są przez Zgromadzenie

${ }^{3}$ Zob. P. Skuczyński, Soft law w perspektywie teorii prawa [w:] System prawny, red. O. Bogucki, S. Czepita, Szczecin 2008, s. 327.

${ }^{4}$ Zob. V. Pergantis, Soft Law, Diplomatic Assurance and the Instrumentalisation of Normativity: Wither as Liberal Promise, "Netherlands Law Review" 2009, No. 2, s. 139.

${ }^{5}$ Zob. C.M. Chinkin, The Challenge of Soft Law: Development and Change in International Law, "International and Comparative Law Quarterly" 1989, No. 4, s. 853.

${ }^{6}$ Zob. L. Lavranos, Jurisdictional Competition: Selected Cases in International and European Law, Europa Law, Groningen 2009, s. 99.

7 Zob. W. Góralczyk, S. Sawicki, Prawo międzynarodowe publiczne w zarysie, Warszawa 2015, s. 61.

${ }^{8}$ Por. W. Bańczyk, „Miękkie prawo, ale prawo”, czyli o obowiązu przestrzegania soft law, „Internetowy Przegląd Prawniczy TBŚP UJ” 2016, nr 1, s. 63, www.tbsp.wpia.uj.edu.pl/documents/ 4137545/127722957/1_bańczyk (dostęp: 26.11.2016 r.).

${ }^{2}$ Zob. H. Klebes, Rola Z Zromadzenia Parlamentarnego Rady Europy w upowszechnianiu standardów demokratycznych $w$ Europie [w:] Polska $w$ Radzie Europy. 10 lat członkostwa. Wybrane zagadnienia, red. H. Machińska, Warszawa 2002, s. 36. 
jedynie w formie oczekiwań. Tworzą one jednak podstawę do monitorowania danego państwa przez pewien czas po jego przyjęciu w poczet członków, który trwa od momentu wyrażenia przez Zgromadzenie zadowolenia z wykonywania wszystkich zobowiązań, albo stwierdzenia w danym kraju odpowiedniej dynamiki w dążeniu do ich spełnienia. Właściwie oznacza to koniec oficjalnego monitoringu, co jednak nie wyklucza kontynuowania poakcesyjnego ${ }^{10}$.

Rola standardów o charakterze soft law, a więc tych z obszaru miękkiego prawa jest tu bardzo istotna. Termin ten odnosi się do pokrewnych prawu instrumentów, które nie posiadają żadnej mocy prawnie wiążącej lub których moc wiążąca jest w jakiś sposób słabsza w porównaniu do mocy wiążącej tradycyjnego prawa, w tym kontekście często określanego jako „twarde prawo” (hard law ${ }^{11}$ ). R. Bierzanek w swojej analizie zagadnienie to ujmuje jeszcze szerzej, wyróżniając (na wzór zachodni) wśród tych regulacji akty przedprawne (para-juridique) i niedoskonałe (lex imperfecta) ${ }^{12}$.

Istnieje pogląd, że po instrumenty ,miękkiego prawa” sięga się m.in. w strukturach międzynarodowych charakteryzujących się słabym typem związania członków, co można zaobserwować na przykładzie Wspólnoty Niepodległych Państw ${ }^{13}$. Można je jednak spotkać w działalności ważnych instytucji międzynarodowych, np. Ombudsmana UE ${ }^{14}$.

Standardy występujące w aktach zaliczanych do kategorii „miękkiego prawa” określa się terminem „standardy uchwałodawcze”. W odniesieniu do takich standardów zawartych w uchwałach Rady Europy pełnią one ważną rolę, bądź inspirując powstanie standardów traktatowych, bądź je uzupełniając ${ }^{15}$.

Występuje jednak różnica pomiędzy standardami umownymi i uchwałodawczymi. Te pierwsze stają się wiążące dla państwa z chwilą przystąpienia do umowy międzynarodowej (konwencji, traktatu). Fakt przyjęcia konwencji przez odpowiedni organ organizacji międzynarodowej nie niesie więc bezpośrednio żadnych konsekwencji prawnych z punktu widzenia obowiązywania standardów. W przypadku natomiast standardów uchwałodawczych, np. zaleceń Komitetu Ministrów RE, do ich obowiązywania nie jest konieczny żaden akt przystąpienia. Z chwilą bowiem przyjęcia ich przez odpowiedni organ Rady Europy, Unii Europejskiej czy też OBWE rozpoczyna się ich życie prawne. Wiążą więc one państwo członkowskie już od momentu ich przyjęcia, ale jest to związanie słabsze, właśnie o charakterze „miękkiego prawa”. Mamy jednak do czynienia z pewną opcyjnością w przypadku standardów uchwałodawczych, która nie wynika z możliwości nieprzystąpieniu (skoro nie ma takiej procedury), ale stąd, że państwo członkowskie może po prostu nie podjąć działań na rzecz wdrożenia takich standardów, wychodząc z założenia, że nie ciąży na nim obowiązek prawny, a z jakichś powodów uważa wprowadzenie tych standardów za niestosowne ${ }^{16}$.

10 Ibidem.

11 K. Spryszak, Obserwowanie wyborów jako instrument implementacji międzynarodowych standardów prawnych $w$ dziedzinie demokracji, Toruń 2015, s. 61.

12 R. Bierzanek, J. Symonides, Prawo międzynarodowe publiczne, Warszawa 2000, s. 116.

13 Zob. R. Dragoneva, Is ,,Soft” Beautiful? Another Perspective on Law, Institutions, and Integration in the CIS, "Review of Central and East European Law" 2004, No. 3, s. 282.

14 Zob. P.G. Bonnor, The European Ombudsman: A Novel Source of Soft Law in the European Union, "European Law Review" 2000, nr 1, s. 39.

15 Zob. C. Mik, Standardy Rady Europy dotyczace prasy, „Palestra” 1993, nr 9-10, s. 97.

16 Zob. A. Jaskiernia, Media masowe $w$ demokratycznych procesach wyborczych: Standardy europejskie i uwarunkowania ich realizacji, Warszawa 2008, s. 188-189. 
Powodem tworzenia standardów międzynarodowych o charakterze miękkiego prawa w wielu przypadkach było to, iż szereg wartości w danej organizacji międzynarodowej nie było znanych in statu nascendi ${ }^{17}$. Do ich rozpoznania doszło natomiast dopiero na dalszych etapach jej rozwoju. W tej sytuacji powstała potrzeba wprowadzenia ich do systemu aksjologicznego ${ }^{18}$. Szczególnie było to widoczne na przykładzie Rady Europy, bowiem w organizacji tej najbardziej doskonałym sposobem tego uzupełnienia było wprowadzenie ich, drogą protokołów dodatkowych, do Europejskiej Konwencji Praw Człowieka, a także zawarcie w nowo przyjmowanych konwencjach. W wielu kwestiach dochodzenie do rozwiązań konwencyjnych jest utrudnione, dlatego postępowanie RE było możliwe dopiero wówczas, gdy materia regulacyjna dojrzała do regulacji konwencyjnej.

Niezależnie jednak od tego aspektu aksjologicznego, według Prof. J. Jaskierni, godną refleksji wydaje się być kwestia: w jaki sposób charakter normy jako „miękkiego prawa” rzutuje na jej funkcjonowanie w porównaniu z normami o charakterze „twardego prawa”, a zwłaszcza jaki ma wpływ na jej wartość logiczną. „Jeśli przyjmiemy, że prawo ma charakter normatywny, to musi być postawione pytanie o wartość normatywną ,,miękkiego prawa"19.

Przepisy prawne stanowi się głównie w celu stosowania norm prawnych, które na ich gruncie się konstruuje ${ }^{20}$, to niewątpliwie normy, skonstruowane na podstawie ,,miękkiego prawa” np. zalecenia Komitetu Ministrów Rady Europy, pod takie rozumienie podpadają. W oparciu o to można zaproponować konkluzję, że status przepisu jako „miękkiego prawa” nie stanowi bariery, by konstruować na jego podstawie normy prawne.

W piśmiennictwie naukowym standardy o charakterze „miękkiego prawa” są określane jako „standardy zalecane”21, mające dużą wagę moralną, będące ,prawem programowym” lub ,prawem celowościowym" "22. Są to więc ,instrumenty i porozumienia, mające zastosowanie w stosunkach międzynarodowych jako wyrażające zobowiązania, które są czymś więcej niż tylko deklaracjami politycznymi, lecz z drugiej strony nie są też stricte prawem"23.

„Miękkie prawo" ma zwykle podobną budowę do „twardego prawa”24 i często jest stanowione przez te same organy, które tworzą akty prawne o mocy wiążącej. Jego postanowienia często nie dotyczą spraw mniej znaczących, ale raczej takich, które ze względu na

${ }^{17}$ Por. J. Jaskiernia, Znaczenie standardów Rady Europy o charakterze ,miękkiego prawa” [w:] Ius est ars boni et equi. Księga pamiątkowa z okazji 5-lecia Wydziatu Prawa Wyższej Szkoty Menedżerskiej w Legnicy, red. N. Szczęch, Legnica 2010.

18 Por. A. Jurewicz, Rola „miękkiego” prawa w praktyce instytucjonalnej Wspólnoty Europejskiej [w:] Implementacja prawa integracji europejskiej w krajowych porzadkach prawnych, red. C. Mik, Torun 1998, s. 111.

19 Zob. J. Jaskiernia, Konstrukcja normy prawnej o charakterze „miękkiego prawa” [w:] Wielowymiarowość prawa. Ksiegga jubileuszowa z okazji 40-lecia pracy naukowej Prof. Krzysztofa Pateckiego, red. J. Czapska, M. Dudek, M. Stępień, Toruń 2014, s. 106.

${ }^{20}$ Zob. A. Jamróz, Wprowadzenie do prawoznawstwa, Warszawa 2008, s. 126.

${ }^{21}$ Zob. A.M. Dereń, A. Kudłaszyk, Zarys europejskiej konwencji wolności radiofonii i telewizji w prawie międzynarodowym [w:] Mass media w systemie komunikacji społecznej, red. A. Kudłaszyk, A. Markiewicz, Wrocław 1995, s. 41.

${ }_{22}$ Zob. R. Bierzanek, J. Symonides, Prawo międzynarodowe publiczne, Warszawa 2000, s. 115-116.

${ }^{23}$ Zob. D. Thürer, Soft law [w:] Encyclopedia of Public International Law, Vl. IV, 2000, s. 454.

${ }^{24}$ C. Mik, Europejskie prawo wspólnotowe. Zagadnienia teorii i praktyki, t. 1, Warszawa 2000, s. 522. 
swoją specyfikę powodują, że niemożliwe lub nieracjonalne byłoby tworzenie prawa w tradycyjnej formie.

W literaturze wskazuje się, iż pewnego rodzaju obowiązek poszanowania ,,miękkiego prawa" - czy to wywodzony z autorytetu organu stanowiącego, $\mathrm{z}$ honorowego charakteru takiego związania, z sankcji za nieprzestrzeganie norm samodzielnie ustalonych przez podmioty je tworzące, czy za sprawą faktycznego wpływu innych podporządkowanych podmiotów - może być też daleko skuteczniejszy od często tylko teoretycznych sankcji. Zaznacza się przy tym, że będzie to miało miejsce zwłaszcza w systemach prawnych wolnych od obecności typowego aparatu przymusu. Biorąc pod uwagę swoisty proces powstawania „miękkiego prawa”. Także tryb jego zmiany jest znacząco ułatwiony oraz sprzyja tworzeniu funkcjonalnie elastycznego prawa ${ }^{25}$.

$\mathrm{Z}$ analizy wynika jednak, iż zagadnienie ,miękkiego prawa” przez wielu badaczy traktowane jest wieloaspektowo, czy wręcz problematycznie. Dla przykładu w literaturze rozważa się kwestie zakresu i stopnia skutków wiążących uchwał i rezolucji prawnie niewiążących, zwłaszcza w związku z Aktem Końcowym KBWE oraz dokumentami finalnymi szczytów KBWE/OBWE. Większość polskich autorów uważa, że dokumenty te nie są prawnie wiążące, lecz mają charakter zobowiązania politycznego ${ }^{26}$. Szerszych skutków dopatrują się tu W. Czapliński i A. Wyrozumska, którzy przestrzeganie najważniejszych postanowień KBWE/OBWE widzą jako proces zmierzający do ustanawiania lub wynikający z norm zwyczajowych ${ }^{27}$. Odróżniają również źródła prawa od źródeł zobowiązań ${ }^{28}$. Z kolei jak podkreśla J. Sozański w literaturze anglosaskiej wielu autorów Akt Końcowy KBWE i ważniejsze dokumenty OBWE zalicza do memorandów porozumienia (Memoranda of Understanding - MOUs), a zobowiązania tego typu uznaje za odrębną kategorię nieformalnych instrumentów międzynarodowych ${ }^{29}$.

Dyskusyjną kwestią pozostaje również charakter prawny zaleceń, uwag końcowych czy opinii organów traktatowych ONZ. Choć nie mają one mocy obowiązującej dla państw, nie oznacza to, że nie mają żadnego znaczenia przy interpretacji traktatu albo przy określaniu wynikających z traktatu zobowiązań państw-stron ${ }^{30}$. V. Dimitrijevic ujął to następująco: „oświadczenie władnego organu, pełniącego ważną funkcję nadzorczą nie może pozostać bez konsekwencji" ${ }^{31}$. Z kolei M. Scheinin eksplorował to stwierdzenie na specyficzny przypadek stwierdzenia przez organ traktatowy naruszenia przez państwo-stronę stosownego traktatu” „,brak wyraźnej klauzuli dotyczącej natury prawomocności tego uznania przez odpowiednią komisję ekspertów w innych traktatach mówiących o prawach człowieka nie oznacza, że to uznanie jest jedynie rekomendacją. Zobowiązania traktatowe są same w sobie wiążące prawnie, a międzynarodowa Komisja ekspertów ustanawiana przez traktat jest

25 W. Bańczyk, „Miękkie prawo’ ale prawo”..., s. 63.

26 Zob. J. Sozański, Prawo traktatów. Zarys wspótczesny (wydanie trzecie rozszerzone i zmienione), Warszawa - Poznań 2009, s. 44.

27 Zob. W. Czapliński, A. Wyrozumska, Prawo międzynarodowe publiczne. Zagadnienia systemowe, wyd. 2, Warszawa 2004, s. 300.

28 Ibidem, s. 420.

${ }^{29}$ Zob. J. Sozański, Prawo traktatów..., s. 45; Por. A. Aust, Modern Treaty Law and Practice, Cambridge 2000, s. 15 i n.

${ }^{30}$ Zob. J. Kondratiewa-Bryzik, Początek prawnej ochrony życia ludzkiego w świetle standardów międzynarodowych, Warszawa 2009, s. 42.

31 V. Dimitrijevic, State Report [w:] International Human Rights Monitoring Mechanisms: Essays in Honour of Jakob Th. Moller, The Hague 2001, s. 198. 
ciałem najbardziej władnym do interpretowania danego traktatu. Dlatego uznanie pogwałcenia traktatu przez organ traktatowy praw człowieka ONZ może być rozumiane jako wskazanie, że państwo-strona jest zobowiązane do naprawy tej sytuacji”32.

Państwa odwołują się do dokumentów o charakterze „miękkiego prawa” celem uniknięcia niekorzystnych sytuacji, które mogą wynikać ich zdaniem ze zobowiązań mających bezwzględnie wiążący charakter. Akty o charakterze soft law służą zatem jako kompromis między suwerennością państwa i potrzebą ustanowienia norm rządzących stosunkami międzynarodowymi. Państwa wybierają je więc celem osiągnięcia modus vivendi kierującego ich postępowaniem w sposób dość elastyczny, bądź umożliwiający drogę do wycofania się z podjętych zobowiązań ${ }^{33}$. Odgrywają one jednak rolę w sferze bezpośrednich skutków prawnych. Są ważne z punktu widzenia „dobrej wiary”, tj. oznaczają, że dany podmiot nie może zaprzeczyć swojemu własnemu postępowaniu (np. nie może dowodzić bezprawności aktów, które sam uprzednio aprobował), a oczekiwania określonych zachowań są chronione przez soft law tak długo, jak są uzasadnione postępowaniem zainteresowanych stron. Prócz tego soft law może przyczynić się do rozwoju źródeł prawa mających wiążący charakter, i to zarówno prawa umownego, jak i zwyczaju. Ponadto Soft law może odegrać rolę wyjaśniającą i precyzującą postanowienia wiążących źródeł prawa międzynarodowego ${ }^{34}$. Istotnym jest zatem dostrzeżenie, że standardy z obszaru „miękkiego prawa” bądź inspirują powstanie standardów traktatowych (wówczas ich znaczenie jest przejściowe), bądź je uzupełniają (wówczas ich znaczenie jest trwałe, jednak pod warunkiem, że materia przez nie regulowana nie nadaje się do ujęcia w standardy traktatowe $)^{35}$.

Choć zatem ,miękkie prawo” wspiera regulacje wielu istotnych kwestii, to badacze tego rodzaju prawa zwracają uwagę na niebezpieczeństwo zbyt licznego budowania takich norm w miejsce typowo sankcjonowanych ${ }^{36}$. Nawet jeśli przyjąć koncepcję, że kreuje ono swoistą postać zobowiązania do przestrzegania, może ona okazać się niewystarczająca ${ }^{37}$. W efekcie może to negatywnie wpłynąć na i tak utrudnione egzekwowanie zobowiązań prawnych, zwłaszcza w prawie międzynarodowym. Drugim niebezpieczeństwem jest nadużywanie go na płaszczyźnie międzynarodowej ,,w celu ominięcia skomplikowanego procesu prawotwórczego i odstąpienia od wymogów wyrażenia formalnej zgody przez państwa" ${ }^{38}$.

W literaturze sygnalizuje się również problem gdy posługiwanie się terminem ,,miękkiego prawa" dotyczy instrumentu konwencyjnego o charakterze ramowym, takiego jak Konwencja Ramowa o Ochronie Mniejszości Narodowych. „Miękkość” ma tu sygnalizować nie charakter prawny dokumentu, a trudności z wyegzekwowaniem w praktyce reguł zawartych w takim dokumencie ${ }^{39}$.

\footnotetext{
${ }^{32}$ M. Scheinin, International Mechanisms and Procedures for Implementation [w:] An Introduction to the International Protection of Human Rights: A Textbook, red. R. Hanski, M. Suksi, Turku Abo 1997, s. 369.

33 Ibidem, s. 453.

34 Ibidem, s. 457-458.

35 Zob. C. Mik, Standardy Rady Europy..., s. 97.

${ }^{36}$ W. Bańczyk, "Miękkie prawo, ale prawo"..., s. 64.

37 Zob. W. Slowmason, Fundamental perspectives on international law, Boston 2011, s. 36.

${ }^{38}$ Zob. W. Czapliński, A. Wyrozumska, Prawo międzynarodowe. Zagadnienia systemowe, wyd. 2, Warszawa 2004. s. 63.

${ }^{39}$ Por. F. Palermo, Domestic Enforcement and Direct Effect of the Framework Convention for the Protection of National Minorities on the Judical Implementation of the (soft?) law of integration
} 
Oddziaływanie Rady Europy na ustrój polityczny państwa zarówno za pomocą standardów soft law jak i hard law wynika zatem z jej podstawowych założeń aksjologicznych ${ }^{40}$. Warto odnieść się do Statutu Rady Europy ${ }^{41}$, który stanowi w przepisie art. 1 pkt. a, że jej celem jest „osiąganie ściślejszego związku między jej członkami, dla ochrony i popierania ideałów i zasad, które stanowią jej wspólne dziedzictwo oraz w celu działania na rzecz ich postępu gospodarczego i społecznego". W przepisie art. 3 stwierdzono przy tym jednoznacznie, ze wszyscy członkowie Rady Europy uznają zasadę rządów prawa, a także zasadę, zgodnie z którą każda osoba podlegająca ich jurysdykcji korzysta z praw człowieka i podstawowych wolności. Członkowie zobowiązani są do lojalnej i aktywnej współpracy w dążeniu do celu określonego w rozdziale I". Dla realizacji tego celu zasadnicze znaczenie ma zatem implementacja Europejskiej Konwencji Praw Człowieka. Oddziałuje ona zarówno na kształt prawa wewnętrznego, jak i na instrumenty pozostające w dyspozycji obywatela ${ }^{42}$.

Statut w art. 15b stanowi, że Komitet Ministrów może prosić rząd państwa członkowskiego o informację, jak realizowane jest zalecenie. Choć więc zalecenie jest niewątpliwie jedynie aktem prawnym o charakterze „miękkiego prawa”, to jednak nie oznacza to, że nie niesie żadnych skutków prawnych. Skoro bowiem statut RE mówi, że Komitet Ministrów może prosić o informację, jak realizowane jest zalecenie, to znaczy, że można domniemywać, iż zalecenie to powinno być realizowane przez państwa członkowskie pomimo tego, że formalnie ma jedynie status „miękkiego prawa”. Problem jednak w ustaleniu, jaki charakter ma ta „powinność” i czy wiąże się z sankcjami. Nie wchodzą tu niewątpliwie sankcje przewidywane np. w Europejskiej Konwencji Praw Człowieka, a więc w akcie międzynarodowym o charakterze prawnie wiążącym. Można co najwyżej rozważać aspekt moralnopolityczny w tym sensie, że skoro Rada Europy jest określana jako „organizacja wartości”43, to państwa, które do niej przystąpiły, powinny realizować jej system aksjologiczny bez względu na to, a jakiej formie został wyartykułowany. Dodatkowym argumentem może tu być to, że zalecenia Komitetu Ministrów z reguły podejmowane są metodą konsensusu. Skoro, więc przedstawiciele państw członkowskich zdecydowali się na poparcie zalecenia, to dali tym samym wyraz gotowości tych państw, by dyspozycje zawarte w zaleceniu realizować.

W systemach aksjologicznych organizacji międzynarodowych istnieją instytucje, które odgrywają zasadniczą rolę w zakresie wdrażania standardów. Dla przykładu taką funkcję Rada Europy przypisuje się Komisarzowi Praw Człowieka ${ }^{44}$. Odgrywa on bardzo ważną

[w:] The Framework Convention for the Protection of National Minorities: a Useful Pan-European Instrument?, red. A. Vertischel et al., Antwerpen 2008, s. 24-32.

40 Zob. J. Jaskiernia, Standardy Rady Europy a ustrój polityczny Polski [w:] Polska w Radzie Europy. 10 lat członkostwa. Wybrane zagadnienia, red. nauk. H. Machińska, Warszawa 2002, s. 93.

${ }^{41}$ Zob. Statut Rady Europy [w:] Regulamin Zgromadzenia Parlamentarnego i Statut Rady Europy, Biuletyn Informacyjny, a.1(36)/1999. Biuro Stosunków Międzyparlamentarnych, Kancelaria Sejmu, Warszawa 1999.

${ }^{42}$ Por. I. Cameron, The Swedish Experience of the Convention on Human Rights Since Incorporation, "International and Comparative Law Quartely" 1999, No. 1, s. 52.

43 Zob. J. Jaskiernia, Rada Europy jako „organizacja wartości” [w:] Wyjaśnianie polityki, red. J. Błuszkowski, J. Zaleśny, „Studia Politologiczne” 2010, Vol. 17, s. 172.

${ }^{44}$ Szerzej: J. Jaskiernia, Komisarz Praw Człowieka Rady Europy: dorobek i perspektywy, „Humanistyczne Zeszyty Naukowe - Prawa Człowieka” 2008, nr 11. 
rolę w kwestii ochrony praw człowieka. Ma on za zadanie m.in. przyczyniać się do promowania efektywnej realizacji i pełnego wdrażania praw człowieka w państwach członkowskich; przeciwdziałać naruszeniu tych praw; identyfikować ewentualne niedostatki w zakresie prawa i praktyki w państwach członkowskich co do przestrzegania praw człowieka określonych w dokumentach RE; promować efektywne wdrażanie tych standardów w państwach członkowskich.

Choć kompetencje Komisarza dotyczą w szczególności praw człowieka, to jednak instytucja ta odgrywa ważną rolę w systemie egzekwowania standardów RE w szerszym zakresie. Warto w tym kontekście podkreślić, że system ochrony praw człowieka jest istotnym elementem ustroju politycznego państwa. Dotyka on przy tym tak podstawowych wartości ustrojowych, jak: praworządność, demokracja, czy też ochrona jednostki. Dlatego też rola Komisarza nie ogranicza się do ochrony wyłącznie tych praw, o których mówi Europejska Konwencja Praw Człowieka, ale uwzględnia całokształt standardów RE, wypracowanych w strukturach tej organizacji międzynarodowej, a rzutujących na kształt systemu politycznego państw członkowskich.

Z kolei w systemie aksjologicznym Unii Europejskiej na szczególną uwagę zasługuje Agencja Praw Podstawowych UE (dalej: APP), której utworzenie jest niewątpliwie istotnym wydarzeniem nie tylko dla UE, ale dla całego europejskiego systemu ochrony praw człowieka, niosącym implikacje dla innych podmiotów tego systemu, a zwłaszcza dla Rady Europy. Powstał bowiem nowy mechanizm ochrony praw podstawowych w UE ${ }^{45}$, który ma przyczyniać się do sprostania wyzwaniom, jakie dla ochrony praw człowieka niesie XXI wiek. Ochrona ta, obok demokracji ma podstawowe znaczenie dla legitymizacji Unii ${ }^{46}$. W literaturze wskazuje się, iż powstanie APP wywołało niemały rezonans w europejskiej opinii publicznej, w organizacjach specjalizujących się w ochronie praw człowieka, a także spotkało się z zainteresowaniem środowisk naukowych ${ }^{47}$.

Jak wynika $z$ art. 2 rozporządzenia ustanawiającego Agencję Praw Podstawowych ${ }^{48}$ jej celem jest ,dostarczanie pomocy i wiedzy fachowej w zakresie praw podstawowych odpowiednim instytucjom, organom, biurom i agencjom Wspólnoty oraz jej państw członkowskich przy wdrażaniu przez nie prawa wspólnotowego; wsparcie to służy pełnemu poszanowaniu praw podstawowych przez te instytucje i organy przy podejmowaniu przez nie środków lub określaniu kierunków działań w dziedzinach należących do ich kompetencji”. Zaznaczono zarazem, że Agencja wykonuje go w ramach kompetencji Wspólnoty określonych w art. 3 ust. 1 Traktatu ustanawiającego Wspólnotę Europejską (TWE), ale podczas wykonywania swych zadań odnosi się do praw określonych w art. 6 ust. 2 Traktatu o Unii Europejskiej (TUE). Chodzi tu o podstawowe zasady zagwarantowane w Europejskiej Konwencji Praw Człowieka oraz ,wynikające z tradycji konstytucyjnych wspólnych dla państw członkowskich, jako zasady ogólne prawa wspólnotowego".

45 Por. A. Wyrozumska, Umocnienie ochrony praw podstawowych, „Prawo Europejskie w Praktyce” 2007, nr 7-8, s. 65.

${ }^{46}$ Zob. C. Hilson, Legitimacy and Rights in the EU, "Journal of European Public Policy" 2007, nr 4, s. 539.

47 Zob. J. Jaskiernia, Agencja Praw Podstawowych Unii Europejskiej, „Państwo i Prawo” 2008, z. 4, s. 3-17.

48 Zob. Rozporządzenie Rady (WE) nr 168/2007 z dnia 15 lutego 2007 r. w sprawie utworzenia Agencji Praw Podstawowych Unii Europejskiej, Dz.Urz. L 053 z 22 lutego 2007, s. 1. 
Trzecim istotnym segmentem europejskiego systemu ochrony praw człowieka jest Organizacja Bezpieczeństwa i Współpracy w Europie (OBWE). Choć organizacja ta kojarzona jest w szczególności z ochroną bezpieczeństwa ${ }^{49}$, to jednak coraz większe znaczenie odgrywa w niej ochrona praw człowieka.

Jednym z przejawów zwiększonego zainteresowania się sprawami demokracji i ochrony praw człowieka stało się utworzenie Biura Instytucji Demokratycznych i Praw Człowieka (Office of Democratic Institutions and Human Rights - ODIHR), którego siedziba znajduje się w Warszawie.

W sferze zainteresowania ODIHR leżą zagadnienia praw człowieka, procesy demokratyzacji, obserwowania wyborów w państwach należących do OBWE. W minionym okresie instytucja ta przeszła gruntowną restrukturyzację. Dziś jest czołową instytucją założoną do monitorowania wyborów. ODIHR jest również wiarygodnym partnerem w międzynarodowych wysiłkach na rzecz pomocy tym krajom ze strefy OBWE, które znajdują się w tzw. okresie przejściowym. Chodzi o stworzenie wspartych na solidnych podstawach systemów demokratycznych, gdzie szanowane są prawa człowieka i przestrzegane jest prawo. Rośnie uznanie międzynarodowe dla roli, jaką odgrywa Biuro.

Na polu demokracji i praw człowieka ODIHR systematycznie analizuje stan ochrony praw człowieka w państwach uczestniczących w OBWE. Realizuje około stu tzw. projektów demokratyzacyjnych w różnych państwach OBWE. Zmierzają one do wzmocnienia społeczeństwa obywatelskiego, jako istotnego czynnika ustanowienia stabilnego demokratycznego społeczeństwa. W ten sposób znacząco przyczynia się do utrwalenia stabilizacji i rozwoju gospodarczego.

Działania ODIHR skoncentrowane są przede wszystkim na różnorodnej pomocy w interwencjach związanych z przypadkami naruszania przyjętych dobrowolnie standardów i zobowiązań, a także promowaniu usług zapobiegających ich powstawaniu lub nawarstwianiu się. Państwa Europy Środkowej i Wschodniej, w dużej mierze pełne euforii po uwolnieniu się z jarzma komunizmu, przyjmując określone standardy czy też do nich dążąc, połączone zostały mimowolnie nicią współzależności, która stale się pogłębia. Przyjmowana od 1975 r. zasada uzależniła poziom stosunków między państwami członkówskimi KBWE od intensywności respektowania przez nie praw człowieka, a konferencja wiedeńska z 1993 r. uznała słusznie, że, o ich ochronę troszczy się cała wspólnota międzynarodowa. Okazuje się jednak, że w odniesieniu do części państw wspólnie wypracowane standardy demokratyczne często nie są najważniejsze ${ }^{50}$, pierwszeństwo mają inne sprawy. Nie zawsze pomaga też potępienie polityczne i inne negatywne dla strony skutki.

Jak wynika z obserwacji inne międzynarodowe i pozarządowe organizacje też działają w wymienionych obszarach, jednak OBWE prowadzi działania właściwe dla tej organiza-

${ }^{49}$ Zob. A. Ackermann, The OSCE and Transnational Security Challenges, "Security and Human Rights" 2009, Vol. 20, No. 3, s. 238-245. Por. R. Dominguez, The OSCE as a Regional Security Actor: a Security Governance Perspective [w:] The Security Governance of Regional Organizations, red. E.J. Kirchner, R. Dominguez, London-New York 2011.

${ }^{50}$ Por. G. Watson, K. Durrant, Liberal Democracy and Globalisation, Langport 2005, s. 34. 
cji $^{51}$. Ma tu miejsce dążenie do osiągnięcia efektu synergii ${ }^{52}$ i komplementarności organizacji międzynarodowych ${ }^{53}$ oraz braku dublowania się ich aktywności ${ }^{54}$.

\section{UWAGI KOŃCOWE}

Tworzenie standardów przez organizacje międzynarodowe jest procesem dynamicznym. Każdy etap rozwojowy danej organizacji przynosi nowe rozwiązania merytoryczne, poszerzające jej dorobek. Należy więc dostrzegać te wymogi, które warunkowały uzyskanie członkostwa na etapie procedury akcesyjnej oraz te, które zostały sformułowane w chwili przyjęcia państwa do organizacji, choć nie warunkowały uzyskania członkostwa, jak również te, które dają o sobie znać już po zakończeniu procedury monitoringowej, a są wyrazem rozwoju polityki np. Rady Europy w odniesieniu do najważniejszych dylematów rozwojowych kontynentu europejskiego. Według. J. Jaskierni na każdym etapie rozwoju tej organizacji międzynarodowej powstają nowe konstrukcje pożądanych zachowań państw członkowskich RE i ich społeczeństw, które mogą być przedmiotem analizy ich urzeczywistniania $^{55}$.

\section{LITERATURA}

[1] Abbott K., Sindal D., Hard and Soft Law in International Governance [w:] International Law: Classic and Contemporary Readings, red. C. KU, P.F. Dietl, Boulder 2009.

[2] Ackermann A., The OSCE and Transnational Security Challenges, "Security and Human Rights" 2009, Vol. 20, No. 3.

[3] Aust A., Modern Treaty Law and Practice, Cambridge 2000.

[4] Bańczyk W., „Miękkie prawo, ale prawo”, czyli o obowiazku przestrzegania soft law, „Internetowy Przegląd Prawniczy TBŚP UJ” 2016, nr 1, s. 63, www.tbsp.wpia.uj.edu.pl/documents/4137545/127722957/1_bańczyk (dostęp: 26.11.2016 r.).

[5] Bierzanek R., Symonides J., Prawo międzynarodowe publiczne, Warszawa 2000.

[6] Bonnor P.G., The European Ombudsman: A Novel Source of Soft Law in the European Union, "European Law Review" 2000, nr 1.

[7] Cameron I., The Swedish Experience of the Convention on Human Rights Since Incorporation, "International and Comparative Law Quartely" 1999, No. 1.

[8] Chinkin C.M., The Challenge of Soft Law: Development and Change in International Law, "International and Comparative Law Quarterly" 1989, nr 4.

[9] Czapliński W., Wyrozumska A., Prawo międzynarodowe publiczne. Zagadnienia systemowe, wyd. 2, Warszawa 2004.

\footnotetext{
${ }^{51}$ Por. D.J. Galbreath, M. Brosig, OSCE [w:] Routledge Handbook on the European Union and International Institutions: Performance, Policy, Power, red. K.E. Jørgensen, K.V. Laatikainen, Abingdon 2013.

52 Zob. D.J. Galbreath, C. Gebhard, Cooperation or Conflict?: Problematizing Organizational Overlap in Europe, Farnham 2010, s. 14.

${ }_{53}$ Zob. B. Møller, European Security: the Roles of Regional Organisations, Farnham 2012, s. 24.

${ }^{54}$ Zob. D. Paunov, Assessing the Success of EU-OSCE Cooperation: a Case of Mutualism?, "Security and Human Rights" 2013, Vol. 24, No. 3-4, s. 375.

55 Zob. J. Jaskiernia, Standardy Rady Europy ..., s. 111-112.
} 
[10] Dereń A.M., Kudłaszyk A., Zarys europejskiej konwencji wolności radiofonii i telewizji w prawie międzynarodowym [w:] Mass media w systemie komunikacji społecznej, red. A. Kudłaszyk, A. Markiewicz, Wrocław 1995.

[11] Dimitrijevic V., State Report [w:] International Human Rights Monitoring Mechanisms: Essays in Honour of Jakob Th. Moller, The Hague 2001.

[12] Dominguez R., The OSCE as a Regional Security Actor: a Security Governance Perspective [w:] The Security Governance of Regional Organizations, red. E.J. Kirchner, R. Dominguez, London-New York 2011.

[13] Dragoneva R., Is ,Soft” Beautiful? Another Perspective on Law, Institutions, and Integration in the CIS, "Review of Central and East European Law" 2004, nr 3.

[14] Galbreath D.J., Brosig M., OSCE [w:] Routledge Handbook on the European Union and International Institutions: Performance, Policy, Power, red. K.E. Jørgensen, K.V. Laatikainen, Abingdon 2013.

[15] Galbreath D.J., Gebhard C., Cooperation or Conflict?: Problematizing Organizational Overlap in Europe, Farnham 2010.

[16] Góralczyk W., Sawicki S., Prawo międzynarodowe publiczne w zarysie, Warszawa 2015.

[17] Hilson C., Legitimacy and Rights in the EU, "Journal of European Public Policy" 2007, nr 4.

[18] Jamróz A., Wprowadzenie do prawoznawstwa, Warszawa 2008.

[19] Jaskiernia A., Media masowe w demokratycznych procesach wyborczych: Standardy europejskie i uwarunkowania ich realizacji, Warszawa 2008.

[20] Jaskiernia J., Agencja Praw Podstawowych Unii Europejskiej, „Państwo i Prawo” 2008, z. 4.

[21] Jaskiernia J., Komisarz Praw Człowieka Rady Europy: dorobek i perspektywy, „Humanistyczne Zeszyty Naukowe - Prawa Człowieka” 2008, nr 11.

[22] Jaskiernia J., Konstrukcja normy prawnej o charakterze „miękkiego prawa”, [w:] Wielowymiarowość prawa. Księga jubileuszowa z okazji 40-lecia pracy naukowej Prof. Krzysztofa Pałeckiego, red. J. Czapska, M. Dudek, M. Stępień, Toruń 2014.

[23] Jaskiernia J., Rada Europy jako „organizacja wartości” [w:] Wyjaśnianie polityki, red. J. Błuszkowski, J. Zaleśny, „Studia Politologiczne” 2010, Vol. 17.

[24] Jaskiernia J., Standardy Rady Europy a ustrój polityczny Polski [w:] Polska w Radzie Europy. 10 lat członkostwa. Wybrane zagadnienia, red. nauk. H. Machińska, Warszawa 2002.

[25] Jaskiernia J., Znaczenie standardów Rady Europy o charakterze „miękkiego prawa” [w:] Ius est ars boni et equi. Księga pamiątkowa z okazji 5-lecia Wydziału Prawa Wyższej Szkoły Menedżerskiej w Legnicy, red. N. Szczęch, Legnica 2010.

[26] Jurewicz A., Rola „miękkiego” prawa w praktyce instytucjonalnej Wspólnoty Europejskiej [w:] Implementacja prawa integracji europejskiej w krajowych porzadkach prawnych, red. C. Mik, Torun 1998.

[27] Klebes H., Rola Zgromadzenia Parlamentarnego Rady Europy w upowszechnianiu standardów demokratycznych $w$ Europie [w:] Polska w Radzie Europy. 10 lat członkostwa. Wybrane zagadnienia, red. H. Machińska, Warszawa 2002.

[28] Kondratiewa-Bryzik J., Początek prawnej ochrony życia ludzkiego w świetle standardów międzynarodowych, Warszawa 2009.

[29] Lavranos L., Jurisdictional Competition: Selected Cases in International and European Law, Europa Law, Groningen 2009. 
[30] Mik C., Europejskie prawo wspólnotowe. Zagadnienia teorii i praktyki, t. 1, Warszawa 2000.

[31] Mik C., Standardy Rady Europy dotyczace prasy, „Palestra” 1993, nr 9-10.

[32] Møller B., European Security: the Roles of Regional Organisations, Farnham 2012.

[33] Palermo F., Domestic Enforcement and Direct Effect of the Framework Convention for the Protection of National Minorities on the Judical Implementation of the (soft?) law of integration [w:] The Framework Convention for the Protection of National Minorities: a Useful Pan-European Instrument?, red. A. Vertischel et. al., Antwerpen 2008.

[34] Paunov D., Assessing the Success of EU-OSCE Cooperation: a Case of Mutualism?, "Security and Human Rights" 2013, Vol. 24, No. 3-4.

[35] Pergantis V., Soft Law, Diplomatic Assurance and the Instrumentalisation of Normativity: Wither as Liberal Promise, "Netherlands Law Review" 2009, nr 2.

[36] Scheinin M., International Mechanisms and Procedures for Implementation [w:] An Introduction to the International Protection of Human Rights: A Textbook, red. R. Hanski, M. Suksi, Turku Abo 1997.

[37] Skuczyński P., Soft law w perspektywie teorii prawa [w:] System prawny, red. O. Bogucki, S. Czepita, Szczecin 2008.

[38] Slowmason W., Fundamental perspectives on international law, Boston 2011.

[39] Sozański J., Prawo traktatów. Zarys wspótczesny (wydanie trzecie rozszerzone i zmienione), Warszawa-Poznań 2009.

[40] Spryszak K., Obserwowanie wyborów jako instrument implementacji międzynarodowych standardów prawnych $w$ dziedzinie demokracji, Torun 2015.

[41] Thürer D., Soft law [w:] Encyclopedia of Public International Law, Vol. IV, 2000.

[42] Watson G., Durrant K., Liberal Democracy and Globalisation, Langport 2005.

[43] Wyrozumska A., Umocnienie ochrony praw podstawowych, „Prawo Europejskie w Praktyce" 2007, nr 7-8.

\section{THE ROLE OF THE STANDARDS OF A SOFT LAW IN AREA OF CREATING OBLIGATIONS IN MEMBER STATES INTERNATIONAL ORGANIZATIONS}

Author shows the basic features of soft law are, moreover, defined - the non-binding and nonsanctioned character. The notion derives from the international public law, quite a specific discipline, based thoroughly on the actual influence of the subjects rather than formalized sanctions. Its is also the source for typical soft law institutions: resolutions of international, international declarations, signed but yet not ratified international treaties, other agreements, e,g. gentelmen's agreements.

Soft law is a type of social rather than legal norm. While there is no accepted definition "soft law", it usually refers to any written international instrument, other than a treaty, containing principles, norms, standards, or other statements of expected behavior. Soft law expresses a preference and not an obligation that state should act, or should refrain from acting, in a specified manner. This expressed preference for certain behavior aims to achieve functional cooperation among states to reach international goals.

Some scholars alternatively or also use the term "soft law" to refer to weak or indeterminant provisions in a binding treaty. The practice of states indicates that this use of the term "soft law", referring to the more hortatory or promotional language of certain treaty provisions, is the more appropriate usage. Treaties are binding and contain legal obligations, even specific commitments are drafted in general or weak terms. It is a misnomer to refer to non-binding instruments as "law", soft or hard, although many scholars commonly do so and, for reasons 
Rola standardów o charakterze soft law...

of convenience and simplicity, the term is used herein as a synonym for normative statements contained in instruments that are not legally-binding.

Keywords: soft law, international public law.

DOI: $10.7862 /$ rz.2017.hss.77

Przestano do redakcji: grudzień $2016 r$.

Przyjęto do druku: grudzień 2017 r. 
